\title{
THE LIMIT STATE DESIGN OF SPUN CONCRETE COLUMNS USING LOAD COMBINATIONS RECOMMENDED BY EN 1990 AND ASCE/SEI 7-05
}

\author{
Antanas Kudzys ${ }^{1}$, Romualdas Kliukas ${ }^{2}$ \\ ${ }^{1}$ KTU Institute of Architecture and Construction, Tunelio g. 60, LT-44405 Kaunas, Lithuania \\ ${ }^{2}$ Vilnius Gediminas Technical University, Saulètekio al. 11, LT-10223 Vilnius, Lithuania \\ E-mail: ${ }^{1}$ antanas.kudzys@gmail.com; ${ }^{2}$ pirmininkas@adm.vgtu.lt \\ Received 13 Feb 2009; accepted 31 Mar 2009
}

\begin{abstract}
The expediency of using precast spun concrete columns of annular cross-sections reinforced by high-strength steel bars is discussed. Test material properties, efficiency factors and resisting compressive stresses of plain and reinforced spun concretes are presented. Modelling a bearing capacity of eccentrically loaded members of annular crosssections is based on the concepts of compression with a bending moment and bending with a concentrical force. The comparison of test and modelling data of concentrically and eccentrically loaded members is analysed. The expediency to use in design practice the approaches of current methods of partial safety factors design (PSFD) legitimated in Europe and load and resistance factors design (LRFD) suggested in the USA and other countries is considered and illustrated by a numerical example.
\end{abstract}

Keywords: spun concrete, high-strength steel, beam-columns, compression test, eccentric loading, limit state design.

\section{Introduction}

A number of advantages with respect to economic, structural and architectural features is characteristic of prefabricated spun concrete building columns (Walochnik 1995). However, the technology advancement promotes the use of spun concrete members only for the poles of high-voltage electrical transmission lines: significant technology advances attach great importance to the strength, lightness and durability of precast spun concrete poles. It may be achieved by improving the quality of materials, introducing new manufacturing methods and using meaningful innovative enhancements to engineering design technology (Oliphant and Wong 2002).

Due to the fundamental examinations carried out at the technology laboratories of the European Union and other countries, new centrifugal techniques to produce spun concrete poles for high-voltage electrical transmission line applications are founded and introduced into production practice. It must be emphasized that new computer controlled machines are installed. They regulate the spinning speeds of moulds during distribution and compacting processes so as not to segregate aggregates of concrete mixes achieving their proper compactness and avoiding wire vibrations of reinforcing cages. These novelties introduced for spun concrete poles suit perfectly for spun concrete columns. However, the possibility to improve effectively the structural quality of poles and columns using prestressed tendons (Quasi 2002) or steel fibres (Kaufman et al. 2005) depends on the type of loadcarrying structures.
The roots of unexpected failures and inadmissible residual deformations of tubular reinforced concrete columns can be traced back not only to gross human design or construction errors but can also be caused by some incorrectly formulated concepts and approaches based on the data of insufficiently quantitative and qualitative investigations. A lack of experimental and theoretical research results hampers the development of the current analysis methods of spun concrete columns of annular cross-sections exposed to diverse loads and their combinations.

The analysis of present test data has revealed that high-strength spun concrete as well as longitudinal mild steel bars may simultaneously reach their maximum resisting stresses only with a very little probability. Besides, the early plastic strains of mild steel bars may disintegrate the materials of a compression member, decrease its ductility and at the same time cause its premature failure or collapse.

On the contrary, the plastic strains of high-strength cold worked steel bars of compression members cannot be displayed. Therefore, there exists a redistribution of ultimate compression forces between steel and concrete components. It increases the probability of avoiding the brittle failure of spun concrete members under concentrical and eccentrical loading (MacGregor 1998; Kuranovas and Kvedaras 2007; Soundararajan and Shanmugsundaram 2008).

Special experimental and theoretical investigations were carried out at the Vilnius Gediminas Technical University (Kudzys et al. 1993; Kudzys and Kliukas 2008a, b). The investigation data helped us analyse the features of 
spun concrete members reinforced by high-strength steel bars, model the stress-strain states of spun concrete columns, provide the unsophisticated approaches for their resistance assessment and collate the formats of their reliability verifications by semi-probabilistic methods.

The main aim of this paper is to compare objectively the limit state design results based on the partial safety factors design (PSFD) and the load and resistance factors design (LRFD) suggested in Europe and the USA, respectively, using the load combinations recommended by EN 1990 and ASCE/SEI 7-05.

\section{The mechanical properties of a spun concrete}

The data of investigations carried out by Vadlūga (1979, 1983), Vadlūga et al. (1996) and Kudzys et al. (1993, 2008) helped structural engineers examine and assess the resistance features of plain and reinforced spun concrete members as precast building columns.

Spun concrete specimens of annular cross-sections were manufactured using crushed granite stone of 5-20 $\mathrm{mm}$ fractions and quartz sand with 2.95-3.05 fineness modulus of $1300-1360 \mathrm{~kg} / \mathrm{m}^{3}$ poured bulk as coarse and fine aggregates of concrete mixes. The compressive strength at 28 days of Portland cement was equal to 40.251.6 MPa. Thus, used mixes belong to high performance concrete mixtures of normal weight spun concrete members (Dilger, Rao 1997). The slump of standard cone of these mixtures was between 30 and $60 \mathrm{~mm}$.

The external diameter of specimens moulded by belt-driven and roller-belt-driven type centrifugal machines was equal to 500 and $260 \mathrm{~mm}$ respectively. The compressive strength of spun concrete in tested hollow cylinder $f_{c 1}$ was equal to $33-53 \mathrm{MPa}$. The mean value of the modulus of elasticity of spun concrete was lower than the values presented in EN 1992-1 (2004) for vibrated normal weight concrete and may be defined as:

$$
E_{c m}=20 \times\left(0.1 f_{c m}\right)^{0.3},
$$

where $f_{c m}$ is the mean value of cylinder concrete strength.

The spun concrete specimens were reinforced by ribbed high-strength steel bars of 10,12 and $14 \mathrm{~mm}$ in diameter. They were uniformly distributed throughout their cross-sectional perimeter. The mean values of $0.2 \%$ proof-stress points, $f_{0.2}$, and tensile strength, $f_{t}$, of cold worked steel bars were 872, 890, 862 and 1060, 1052, $1138 \mathrm{MPa}$, respectively.

The investigations showed that the failure of compressed spun concrete members reinforced by highstrength steel bars may be treated as a ductile one (Fig. 1). A relatively brittle failure of some specimens occurred when the geometrical reinforcement ratio, $\rho=A_{s} / A_{c}$, was less than $3 \%$, where $A_{s}$ and $A_{c}$ are cross-sectional areas of reinforcement and concrete sections. The test results showed that its value of 3-6\% may be considered as a rational reinforcement ratio of spun concrete members reinforced by high-strength steel bars.

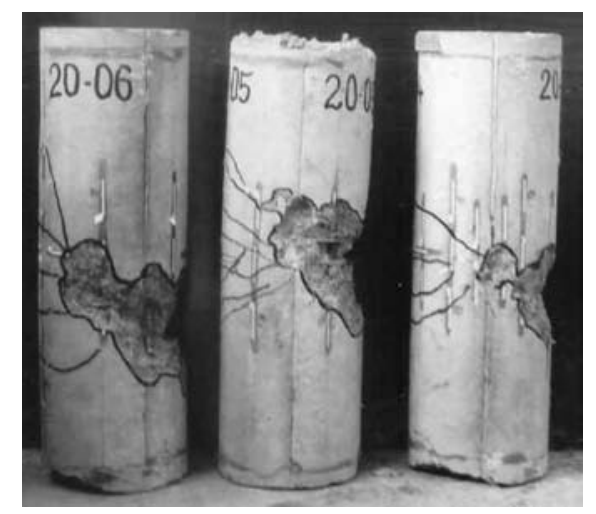

Fig. 1. The characteristic view of eccentrically compressed reinforced members

A sustained loading of concrete structures with permanent and quasi-permanent loads provokes microcracks and creep strains of compressed concrete. According to Diniz $(2002,2005)$, the reduction factor for the compressive strength of column concrete may be defined as $\alpha_{c c}=1-0.2 N_{P} / N_{E}$, where $N_{E}$ and $N_{P}$ are an applied force and its permanent component.

High-strength spun concrete belongs to building materials with fairly high micro-cracking and low creep parameters. The residual micro-cracks usually appear when compressive stresses of spun concrete are equal to $(0.7-0.9) f_{c 1}$, where $f_{c 1}$ is its compressive strength in hollow cylinders which is close to a prism strength. Therefore, the reduction factor for concrete strength of spun concrete columns may be expressed as:

$$
\alpha_{c c}=1-0.1 N_{P} / N_{E} .
$$

The spun concrete members of annular cross-section belong to thin-walled reinforced concrete structures. Their longitudinal reinforcing bars and spiral wires hinder the distribution and compacting of a concrete mix and in this way the compression strength $f_{c 1}$ of spun concrete decreases to the value $f_{c 2}$ (Fig. 2). The ratio of these strengths is equal to $0.82-0.95$ and may be defined as:

$$
f_{c 2} / f_{c 1}=0.95-1.85 \rho,
$$

where $\rho=A_{S} / A_{c}$ is a reinforcement ratio.

The ratio of concrete strength in hollow and solid cylinders may be expressed as $f_{c 1} / f_{c} \approx 0.9$. Thus, the reduction factor, characterizing the ratio of spun concrete strengths in reinforced members and plain concrete cylinders, may be presented as:

$$
\alpha_{2}=f_{c 2} / f_{c}=0.85-1.7 \rho \text {. }
$$

This ratio may be assumed as equal to 0.85 when computer controlled centrifugal machines are used.

The compressive strength of spun concrete in structures may be presented in the form:

$$
f_{c c}=\alpha_{c c} \alpha_{2} f_{c} \text {. }
$$

Due to a redistribution of compressive stresses of high-strength steel bars and spun concrete, the failure strains of compression members are fairly large. Therefore, the maximum values of spun concrete strains and at 
the same time of resisting compressive stresses in reinforcing steel bars of concentrically and eccentrically loaded columns may be defined, respectively, as:

$$
\begin{gathered}
\varepsilon_{c u}^{\prime}=2.26(1.18+4 \rho) 10^{-3}, \\
\sigma_{s c}^{\prime}=\varepsilon_{c u}^{\prime} E_{s}=4.52(1.18+4 \rho) 10^{2} \mathrm{MPa}, \\
\varepsilon_{c u}=2.26(1.36+4 \rho) 10^{-3}, \\
\sigma_{s c}=\varepsilon_{c u} E_{s}=4.52(1.36+4 \rho) 10^{2} \mathrm{MPa} .
\end{gathered}
$$

These values are close to stresses calculated by Hussaini et al. (1993) recommendations.

The test data disclosed that high-strength and highelastic reinforcing bars decrease the coefficient of variation of concrete strains under the failure of reinforced compression members. Therefore, the use of these bars instead of mild steel ones may efficiently increase the structural safety of spun concrete columns.

\section{The bearing capacity of annular cross-sections}

The analysis of ultimate load effects may be based on a plane cross-section hypothesis and bi-linear concrete stress-strain relation, when the conventional concrete strain $\varepsilon_{c 3}$ is equal to $0.5 \varepsilon_{c u}$ (Fig. 2). This value is close to strains $\varepsilon_{c 3}$ recommended by EN 1992-1 (2004).

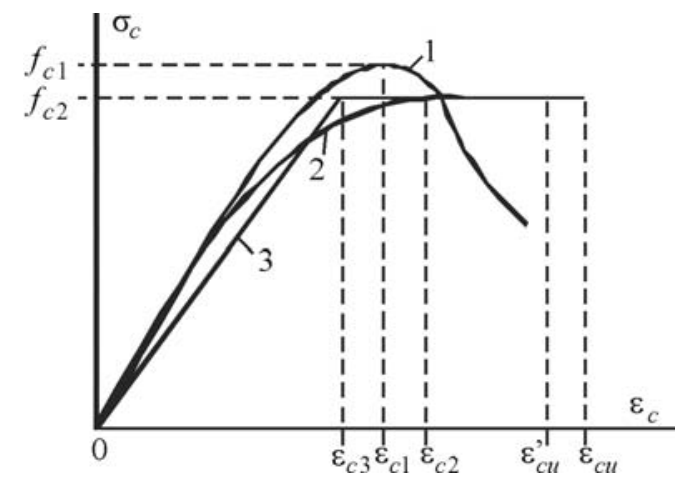

Fig. 2. Stress-strain relations for plain concrete (1) and reinforced concrete by typical (2) and bi-linear (3) laws

According to the design model, presented in Fig. 3, the resisting compressive force, the resisting bending moment caused by this force and its eccentricity are:

$$
N_{R}=N_{c 1}-N_{c 2}+N_{s c}-N_{s t}
$$

$$
\begin{gathered}
M_{R}=N_{c 1} y_{c 1}-N_{c 2} y_{c 2}+N_{s c} y_{s c}+N_{s t} y_{s t}, \\
e=M_{R} / N_{R} .
\end{gathered}
$$

When the eccentricity ratio $e / r_{s} \leq 1$, the response factors of the compressive resistance of concrete and reinforcement can be presented in the forms:

$$
\begin{aligned}
& k_{c}=\frac{N_{c 1}\left(y_{c 1}+r_{s}\right)-N_{c 2}\left(y_{c 2}+r_{s}\right)}{A_{c} f_{c c} r_{s}} \approx 1-\frac{0.3 e / r_{s}}{1+10 \rho}, \\
& k_{s}=\frac{N_{s c}\left(y_{s c}+r_{s}\right)-N_{s t}\left(r_{s}-y_{s t}\right)}{A_{s} \sigma_{s c}^{\prime} r_{s}} \approx 1-0.34 e / r_{s},
\end{aligned}
$$

where $f_{c c}$ is given by (5), $\sigma_{s c}^{\prime}$ by Eq. (7); $A_{c}, A_{s}, r_{s}$ and $\rho=A_{s} / A_{c}$ are the geometrical parameters. In the numerators and denominators of Eqs (13) and (14), the moments of inner concrete and reinforcement forces of eccentrically and concentrically loaded members with respect to point $\mathrm{B}$ of cross-sections (Fig. 3) are given, respectively. The usability of Eqs (13) and (14) in design practice is illustrated by Fig. 4.

The resisting compressive force and bending moment of eccentrically loaded members of annular crosssections may be expressed as:

$$
\begin{gathered}
N_{R}=\left[k_{c} 0.5\left(1+r_{c} / r_{s}\right) A_{c} f_{c c}+k_{s} A_{s} \sigma_{s c}\right] r_{s} /\left(e+r_{s}\right) \approx \\
\approx\left(k_{c} A_{c} f_{c c}+k_{s} A_{s} \sigma_{s c}\right) r_{s} /\left(e+r_{s}\right), \\
M_{R}=N_{R} e,
\end{gathered}
$$

where $k_{c}$ is given by Eq. (13), $k_{s}$ by Eq. (14), $\sigma_{s c}$ by Eq. (9). When these members are concentrically loaded, the factors $e=0, k_{c}=k_{S}=1$ and Eq. (15) is presented in the form

$$
N_{R}=A_{c} f_{c}+A_{s} \sigma_{s c}^{\prime}
$$

where $\sigma_{s c}^{\prime}$ is defined by Eq. (7).

When an eccentricity of applied forces is large, it is more expedient to treat tubular columns as members exposed to bending with concentrical force. According to Vadlūga (1983), at large values of compressive force eccentricity, the ultimate bending moment of annular cross-sections (Fig. 5) reinforced by mild steel bars could be calculated using the peculiar expression:

$$
M_{R}=1.2 r_{s}\left(A_{s} f_{s t}+N_{R}\right)\left(1-\alpha_{c}\right) \text {. }
$$

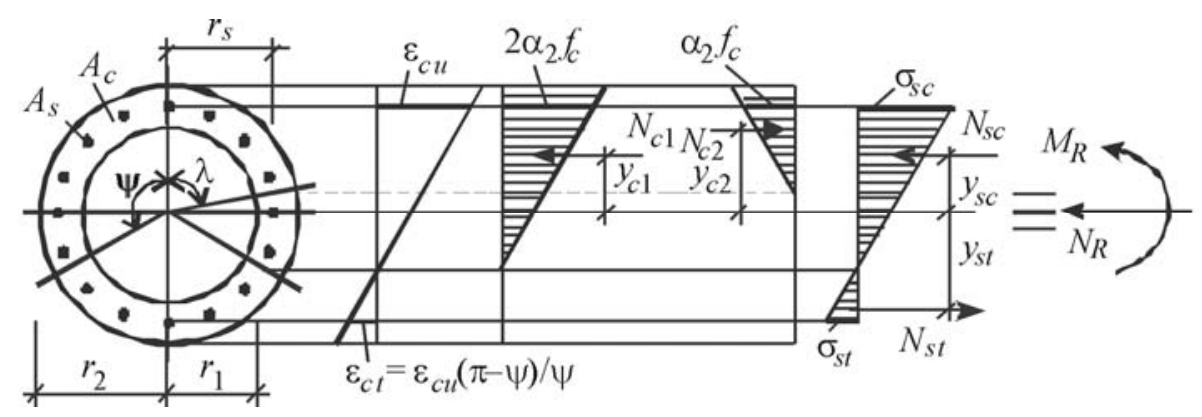

Fig. 3. Modelling of linear strain and stress distributions in the concrete and high-strength steel of eccentrically loaded annular cross-sections 

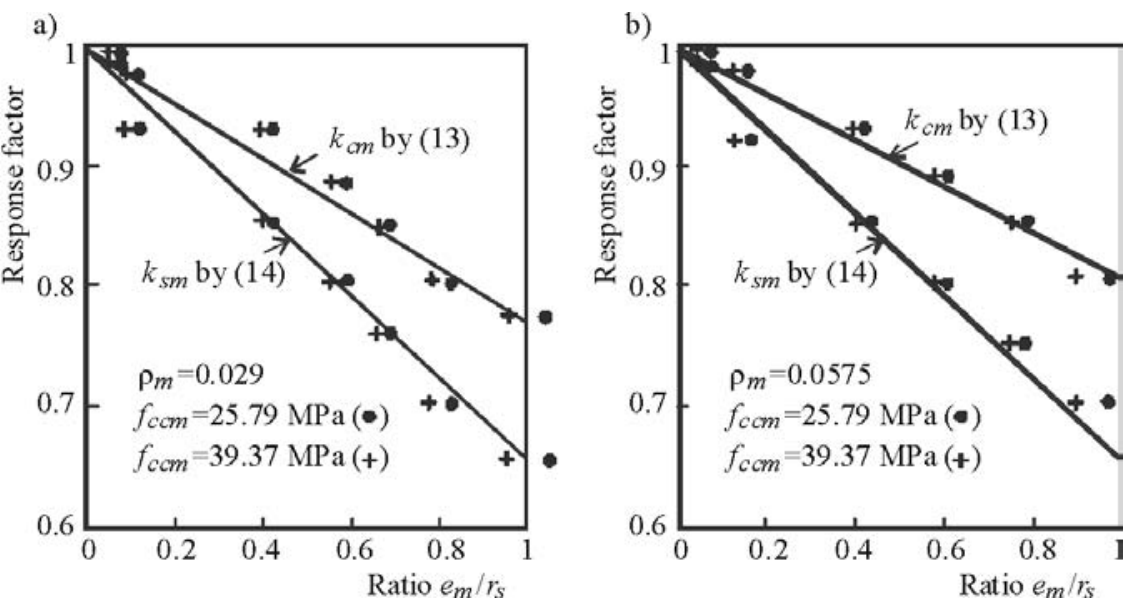

Fig. 4. Mean values of response factors of concrete $k_{c m}$ by (13) and reinforcement $k_{s m}$ by (14) versus the eccentricity ratio $e_{m} / r_{s}$ : a-medium reinforcing; $\mathrm{b}$-strong reinforcing

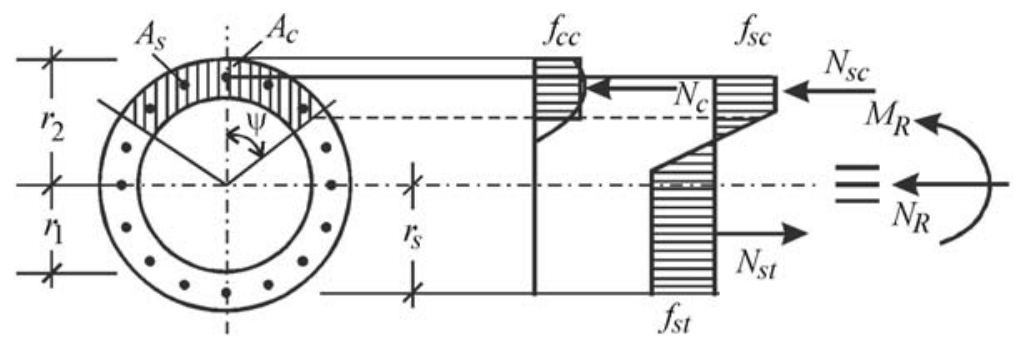

Fig. 5. Modelling of simplified stresses in the concrete and steel of eccentrically loaded annular cross-sections

Here the conventional value of the compression zone of sections is:

$$
\begin{aligned}
& \alpha_{c}=\psi / \pi=\left(0.5\left(1+r_{c} / r_{s}\right) A_{s} f_{s t}+N_{R}\right) /\left[A_{c} f_{c c}+\right. \\
& \left.A_{s}\left(f_{s t}+f_{s c}\right)\right] \approx\left(A_{s} f_{s t}+N_{R}\right) /\left[A_{c} f_{c c}+\right. \\
& \left.A_{s}\left(f_{s t}+f_{s c}\right)\right],
\end{aligned}
$$

where $r_{c}$ and $r_{s}$ are the radii of concrete and steel circles; $f_{s t}$ and $f_{s c}$ - the tensile and compressive strength of longitudinal bars; $A_{s}$ and $A_{c}$ - the areas of steel reinforcement and concrete in the column cross-section; $N_{R}$ represents the concentrical force; $f_{c c}$ by Eq. (5) is the compressive strength of concrete in tubular columns.

An analysis of Eq. (18) revealed its universality. When the tubular members are reinforced by high-strength steel bars, the mean values of conventional strengths in tension and compression of reinforcement should be defined as: $f_{\text {stm }}=500 \mathrm{MPa}$ and $f_{\text {scm }}=600 \mathrm{MPa}$.

The acceptability of Eqs (15) and (17) in the loadcarrying capacity analysis of concentrically and eccentrically loaded tubular members is illustrated by Fig. 6 . The means and standard deviations of the parameter which contains uncertainties of these equations and the peciluar expression by Eq. (18), are equal to $\theta_{R N m}=0.987 \approx 0.99$, $\boldsymbol{\sigma} \theta_{R N} \approx 0.08$ and $\theta_{R M m}=1.016 \approx 1.02, \quad \boldsymbol{\sigma} \theta_{R M} \approx 0.08$ (Vadlūga 1979) for compression (Section 3.1) and bending (Section 3.2) members, respectively.

\section{Limit state design of eccentrically loaded columns}

\subsection{Compressive force and its eccentricity}

The combined effects of building columns are caused by permanent $G$, sustained $Q_{S}(t)$ and extraordinary $Q_{e}(t)$ live loads, snow $S(t)$ and wind $W(t)$ actions. The timevariant extreme live and climate loadings of structures belong to persistent design situations in spite of the short period of extreme events, it being much shorter than the designed working life of buildings. The selected design situations and the relevant limit states in design models of columns depend on the combination of variable actions that are considered to occur simultaneously.

The duration of annual extreme live loads $d_{Q}$ is fairly short and equal to 1-14 days for commercial and 1-3 days for other buildings (JCSS 2000). Their renewal rates $\lambda_{Q}=1 / t_{\lambda}=1 /$ year. Thus, during $t_{n}=50$ years service period, the average recurrence number of extreme annual live loads simultaneously on 2 and 3 storeys, respectively, are: $n_{2}=2 t_{n} d_{Q} \lambda_{Q}^{2}=0.27-0.82 \quad$ and $n_{3}=3 t_{n} d_{Q}^{2} \lambda_{Q}^{3}=0.001-0.01$. In design practice, this unfavourable combination of loads may be neglected.

The durations of annual extreme climate loads may be treated as: $d_{S}=14-28$ days and $d_{W}=8-12$ hours (Ellingwood 1981, JCSS 2000). Therefore, the average recurrence number of joint annual simultaneous extreme floor live and snow or wind loads during $t_{n}=50$ years period is equal to 


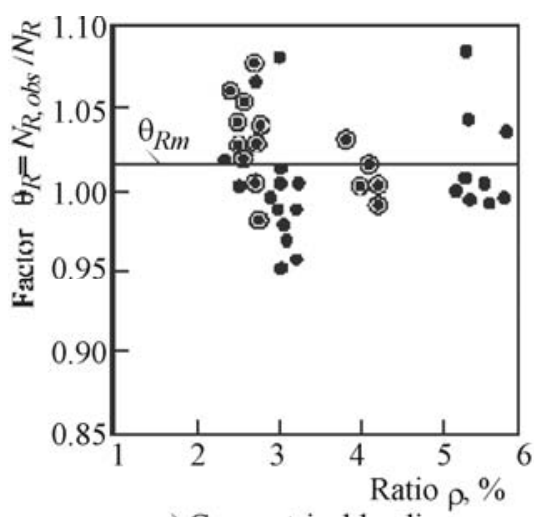

a) Concentrical loading

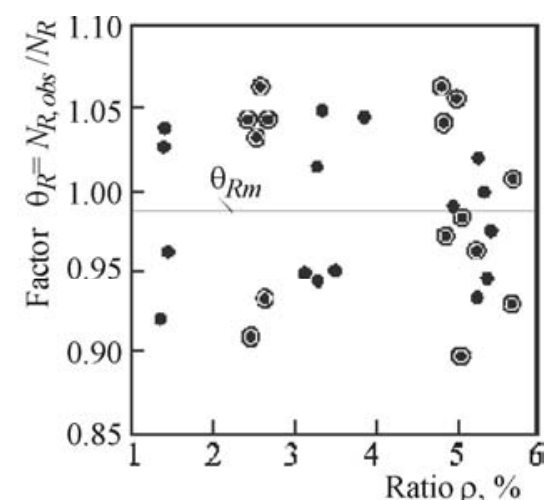

b) Eccentrical loading

Fig. 6. Comparison of the observed and calculated by Eqs (15) and (17) values of resisting

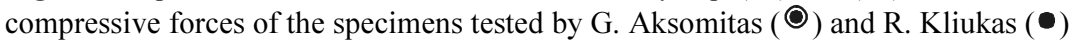

$n_{Q W}=t_{n}\left(d_{Q}+d_{W}\right) \lambda_{Q} \lambda_{W}=0.2-2$ and $n_{S W}=t_{n}\left(d_{S}+d_{W}\right) \lambda_{S} \lambda_{W}=$ 1.96-3.9. The effect of these recurrences of joint variable loads on the limit state verification of structures is associated with the factors for combination values of variable actions recommended by EN 1990 (2002) and ASCE/SEI 7-05 (2006).

Usually, the ends of precast columns of frames are not fully rigidly restrained in in-situ concrete foundations and floors of buildings. Both ends of precast columns are only elasticity restrained at precast floors. Therefore, a slenderness for precast columns of multi-storey frames with in-situ and precast beams may be checked, respectively, with an effective length $l_{0}=0.75 h_{s}$ and $l_{0}=h_{s}$, where $h_{s}$ is a storey height.

The second-order eccentricities of the characteristic and design applied compressive forces $N_{E k}$ and $N_{E d}$ are:

$$
e_{k}=e_{o k} \eta_{k} \text { and } e_{d}=e_{o d} \eta_{d},
$$

but not less as $r_{2} / 15$ and $20 \mathrm{~mm}$.

Here

$$
e_{o k}=M_{O E k} / N_{E k} \text { and } e_{o d}=M_{O E d} / N_{E d}
$$

are the first-order eccentricities of compressive forces and $\eta_{k}=1 /\left(1-N_{E k} / N_{B k}\right)$ and $\eta_{d}=1 /\left(1-N_{E d} / N_{B d}\right)$

are the factors of second-order moment effect, where the buckling loads of concentrically loaded columns may be written in the forms:

$$
N_{B k}=\pi^{2}(E I)_{e k} / l_{o}^{2} \text { and } N_{B d}=\pi^{2}(E I)_{e d} / l_{o}^{2} \text {. }
$$

These buckling loads are based on the characteristic and design flexular stiffness of columns, when the basic value of concrete creep ratio under normal inside environmental conditions is equal to $\Phi=1.2-2.0$ (EN 1992-1 2004).

The characteristic and design factors for concrete cracking and creep effects may be expressed as:

$$
K_{c k} \approx K_{c d}=0.25 /\left(1+\Phi M_{O G d} / M_{O E d}\right),
$$

where $M_{O G d}$ and $M_{O E d}$ are the first-order bending moments caused by permanent and total loads.
According to EN 1990 (2002) recommendations, the characteristic and design values of the effective flexular stiffness of columns may be defined as:

$$
(E I)_{e k}=(E I)_{e d}=K_{c d} E_{c d} I_{c m}+E_{s} I_{s}
$$

where the design value of the modulus of elasticity of concrete $E_{c d}=E_{c m} / 1.2$;

$$
I_{c m}=\pi\left(r_{2}^{4}-r_{1 m}^{4}\right) / 4 \text { and } I_{s}=\pi\left(r_{s 2}^{4}-r_{s 1}^{4}\right) / 4
$$

are the second moments of concrete and reinforcement cross-sectional areas about the centre of annular crosssections.

\subsection{Reliability verification formats}

When the reliability verification of building columns is based on the semi-probabilistic (Level I) approaches, according to the EN 1990 (2002) recommendations, the total design axial force of columns of multistorey frames should be:

$$
N_{E d}^{E N}=\left(N_{G k} \gamma_{G}+K_{F 1} N_{1 k} \gamma_{1}+N_{2 k} \psi_{0} \gamma_{2}\right) \text {, }
$$

where $K_{F 1}=0.9 ; 1.0$, and 1.1 is the efficiency factor for variable loads when the reliability class of structures is RC1, RC2 and RC3; $N_{G k}, N_{1 k}$ and $N_{2 k}$ are the characteristic (nominal) values of permanent, leading and accompanying variable components; $\gamma_{G}=1.35$ and $\gamma_{1}=\gamma_{2}=1.5$ are the partial safety factors for loads; $\psi_{0}=0.7$ is the factor for combination value of a live variable actions, $\psi_{0}=0.5$ and 0.6 for snow and wind load, respectively, in combination of actions. The value $N_{G k}$ is different for propped and unpropped precast continuous beams (Kudzys et al. 2007).

Usually, the radius mean of spun concrete crosssections $r_{c m}=0.5\left(r_{1 m}+r_{2}\right)$ is equal or close to the radius $r_{s}$ of a circle of reinforcing bars. Thus, according to the current partial safety factors design (PSFD) used in Europe, the design values of resisting compressive forces by Eq. (15) and bending moments by Eq. (18) may be expressed in the following forms:

$$
N_{R d}^{E N}=\left(k_{c d}^{E N} A_{c m} f_{c d}^{E N}+k_{s d}^{E N} A_{s} \sigma_{s c d}\right) r_{s} /\left(e_{d}^{E N}+r_{s}\right) \text {, }
$$




$$
\begin{aligned}
& M_{R d}^{E N}=1.2 r_{s}\left(A_{s} f_{s t d}+N_{E d}^{E N}\right) \times \\
& {\left[1-\frac{A_{s} f_{s t k} / \gamma_{s}+N_{E d}}{A_{c m} f_{c d}^{E N}+A_{s}\left(f_{s t d}+f_{s c d}\right)}\right],}
\end{aligned}
$$

where $\rho_{m}=A_{s} / A_{c m}, \quad e_{d}^{E N}$ is given by Eq. (20), $k_{c d}^{E N}=1-0.3 e_{d}^{E N} /\left[r_{s}\left(1+10 \rho_{m}\right)\right]$,

$k_{s d}^{E N}=1-0.34 e_{d}^{E N} / r_{s} ; f_{c c d}^{E N}=\alpha_{c c d}^{E N} \alpha_{2} f_{c k} / \gamma_{c}$,

$\sigma_{s c d}=\sigma_{s c t} / \gamma_{s}=\sigma_{s c m} / \gamma_{s}, f_{s t d}=f_{s t k} / \gamma_{s}=0.9 f_{s t m} / \gamma_{s}$,

$f_{s c d}^{\prime}=f_{s c k} / \gamma_{s}=0.9 f_{s c m} / \gamma_{s}$ are the design values of concrete and reinforcement resistances; $\gamma_{c}=1.5$ and $\gamma_{s}=1.15$ are the partial factors for the concrete and reinforcement properties; $N_{E d}^{E N}$ is the design value of the total compressive force.

Using the PSFD method, the structural design of columns is considered to be sufficient, if the ultimate limit state of columns is not exceeded. This requirement is expressed as $N_{R d}^{E N} \geq N_{E d}^{E N}$ and $M_{R d}^{E N} \geq N_{E d}^{E N} e_{d}^{E N}$.

Combining factored loads by ASCE/SEI 7-05 (2006) directions, the design value of the total compressive force of multistorey frames should be expressed as follows:

a)

$$
\begin{gathered}
N_{E d}^{A S C E}=N_{G k} \gamma_{G}+N_{Q k} \gamma_{Q 1}+N_{S k} \gamma_{S 2} \\
\text { or } N_{E d}^{A S C E}=N_{G k} \gamma_{G}+N_{S k} \gamma_{S 1}+N_{Q k} \gamma_{Q 2}
\end{gathered}
$$

for columns of non-sway frames;

b) Eqs (30) or (31) or

$$
N_{E d}^{A S C E}=N_{G k} \gamma_{G}+N_{W k} \gamma_{W 1}+N_{Q k} \gamma_{Q 2}+N_{S k} \gamma_{S 2}
$$

for columns of multistorey sway frames;

c)

$$
\begin{gathered}
N_{E d}^{A S C E}=N_{G k} \gamma_{G}+N_{S k} \gamma_{S 1}+N_{W k} \gamma_{W 2} \\
\text { or } N_{E d}^{A S C E}=N_{G k} \gamma_{G}+N_{W k} \gamma_{W 1}+N_{S k} \gamma_{S 2}
\end{gathered}
$$

for columns of single-storey sway frames, where $N_{G k}$, $N_{Q k}, N_{S k}$ and $N_{W k}$ are the components caused by characteristic permanent $Q$, variable occupancy $Q$, snow $S$ and wind $W$ loads. The values of partial safety factors for loads are: $\gamma_{G}=1.2, \gamma_{Q 1}=1.6, \gamma_{Q 2}=0.5$ or 1.0 (when uniformly distributed live loads are not more and more than $4.8 \mathrm{kN} / \mathrm{m}^{2}$, respectively), $\gamma_{S 1}=1.6$, $\gamma_{S 2}=0.5, \gamma_{W 1}=1.6$ and $\gamma_{W 2}=0.8$.

According to the current load and resistance factors design (LRFD) used in the USA and some other countries, the design values of compressive forces by Eq. (15) and bending moments by Eq. (18) and may be presented as follows:

$$
\begin{aligned}
& N_{R d}^{A S C E}=\Phi N_{R k}=\Phi\left(k_{c k} A_{c m} f_{c c k}+k_{s k} A_{s} \sigma_{s c k}\right) \times \\
& r_{s} /\left(e_{k}+r_{s}\right), \\
& M_{R d}^{A S C E}=\Phi M_{R k}=\Phi 1.2 r_{s}\left(A_{s} f_{s t k}+N_{E k}\right) \times
\end{aligned}
$$

$$
\left[1-\frac{A_{s} f_{s t k}+N_{E k}}{A_{c} f_{c k}+A_{s}\left(f_{s t k}+f_{s c k}\right)}\right],
$$

where $e_{k}$ is given by Eq. (20);

$k_{c k}=1-0.3 e_{k} /\left[r_{s}\left(1+10 \rho_{m}\right)\right], k_{s k}=1-0.3 e_{k} / r_{s}$;

$f_{c c k}=\alpha_{c c k} \alpha_{2} f_{c k}, \sigma_{s c k}=\sigma_{s c m}, f_{\text {stk }}=0.9 f_{s t m}$,

$f_{s c k}=0.9 f_{s c m}$ are the characteristic values of concrete and reinforcement parameters; $N_{E k}$ is the characteristic value of the total compressive force; $\Phi$ - the strength reduction factor as the global uncertainty factor for compressive resistances of columns. According to ACI 31805 (2005) directions and Szerszen et al. (2005) recommendations, for columns exposed to compression with a small bending moment, this factor is equal to 0.60-0.70. For the spun concrete columns it may be selected as $\Phi=0.65$.

The reliability of columns is sufficient if the destroying force $N_{E d}^{A S C E}$ and moment $M_{E d}^{A S C E}$ are not more than the values $N_{R d}^{A S C E}$ by Eq. (35) and $M_{R d}^{A S C E}$ by Eq. (36). When the destroying moments in unbraced columns are large, it may be necessary to check the reliability of columns subjected to the maximum moment combined with the minimum compressive force (Mosley et al. 2007).

\section{Numerical illustration}

The spun concrete column at the first-floor level of braced multistorey frames of Reliability Class RC2 by EN 1990 (2002) or Category II by ASCE/SEI 7-05 (2006) is under exposure of permanent, $G$, variable live, $Q=Q_{s}+Q_{e}$, and snow, $S$, action effects (Fig. 7). The multification factor for unfavourable variable actions $K_{f_{1}}=1.0$. The characteristic and design values of action effects are presented in Table 1.

The geometrical parameters of a spun concrete column are:

$l_{\text {om }}=3.0 \mathrm{~m}, \quad r_{2}=0.15 \mathrm{~m}, \quad r_{1 m}=0.09 \mathrm{~m}, \quad r_{s}=0.12 \mathrm{~m}$, $A_{m}=0.04524 \mathrm{~m}^{2}, \quad A_{s}=0.00181 \mathrm{~m}^{2} \quad(16 \varnothing 12)$, $A_{c m}=A_{m}-A_{s}=0.0434 \mathrm{~m}^{2}, \quad \rho_{m}=A_{s} / A_{c m}=0.0417$, $I_{m}=\pi\left(r_{2}^{4}-r_{1 m}^{4}\right) / 4=346 \times 10^{-6} \mathrm{~m}^{4}, \quad I_{s}=\pi\left(r_{s 2}^{4}-r_{s 1}^{4}\right) / 4=$ $1.3 \times 10^{-6} \mathrm{~m}^{4}$.

The parameters of the spun concrete C50/60 are given by:

$f_{c k}=50 \mathrm{MPa}, \alpha_{2}=0.85-1.7 \times 0.0417=0.779, \quad \gamma_{c}=1.5$,

$\alpha_{c c k}=1-0.1 N_{G k} / N_{E k}=0.9114$,

$f_{c c k}=0.9114 \times 0.779 \times 50=36.48 \mathrm{MPa}$,

$\alpha_{c c d}^{E N}=1-0.1 N_{G d} / N_{E d}=0.9126$,

$f_{c c d}^{E N}=0.9126 \times 779 \times 50 / 1.5=23.7 \mathrm{MPa}$,

$E_{c m}=20\left(0.1 \times f_{c m}\right)^{0.3}=38.89 \mathrm{GPa}$,

$E_{c d}=E_{c m} / 1.2=28.24 \mathrm{GPa}$. 


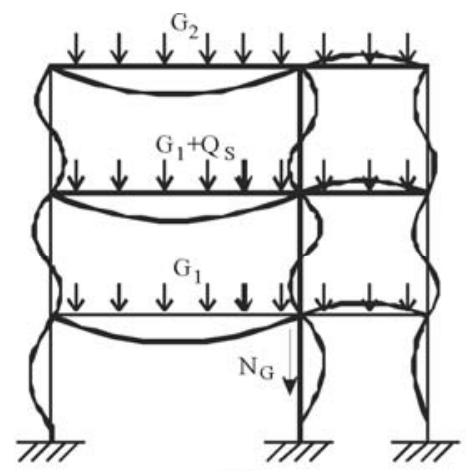

(a)

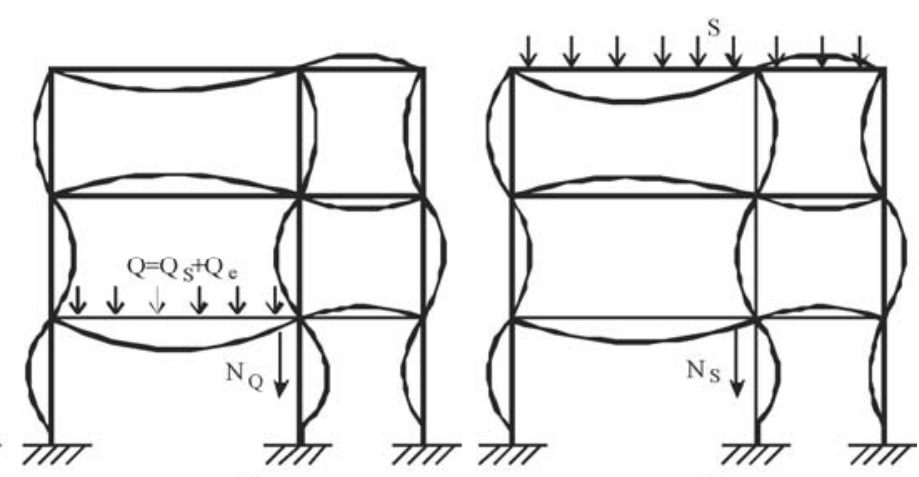

(b)

(c)

Fig. 7. The compressive forces $N_{G}, N_{Q}$ and $N_{S}$ caused by permanent (a) and variable extreme floor (b) or snow (c) loads

Table 1. Compressive forces and first order bending moments

\begin{tabular}{l|c|c|c|c|c|c|c|c}
\hline \multicolumn{1}{c|}{ Action effects } & $\begin{array}{c}N_{G} \\
\mathrm{kN}\end{array}$ & $\begin{array}{c}M_{O G} \\
\mathrm{kNm}\end{array}$ & $\begin{array}{c}N_{Q} \\
\mathrm{kN}\end{array}$ & $\begin{array}{c}M_{O Q} \\
\mathrm{kNm}\end{array}$ & $\begin{array}{c}N_{S} \\
\mathrm{kN}\end{array}$ & $\begin{array}{c}M_{O S} \\
\mathrm{kNm}\end{array}$ & $\begin{array}{c}N_{E} \\
\mathrm{kN}\end{array}$ & $\begin{array}{c}M_{O E} \\
\mathrm{kNm}\end{array}$ \\
\hline Characteristic values & 612.0 & 28.80 & 65.00 & 16.25 & 28.00 & 3.50 & 705.0 & 48.55 \\
\hline Design values by EN 1990 & 826.2 & 38.88 & 97.50 & 24.37 & 21.00 & 2.62 & 944.7 & 65.88 \\
\hline Design values by ASCE 7-05 & 734.4 & 34.56 & 104.00 & 26.00 & 14.00 & 1.75 & 825.4 & 62.31 \\
\hline
\end{tabular}

The parameters of reinforcing high-strength cold worked bars are defined as follows:

$f_{0.2 k}=800 \mathrm{MPa}$,

$\sigma_{s c m}=\sigma_{s c k}=2.26\left(1.36+4 \rho_{m}\right) \times 10^{-3} \times E_{s}=690 \mathrm{MPa}$,

$\gamma_{s}=1.15, \sigma_{s c d}=690 / 1.15=600 \mathrm{MPa}, f_{s t m}=500 \mathrm{MPa}$,

$f_{\text {stk }}=0.9 \times 500=450 \mathrm{MPa}, f_{\text {std }}=450 / 1.15=390 \mathrm{MPa}$,

$f_{\text {scm }}=600 \mathrm{MPa}, f_{\text {sck }}=0.9 \times 600=540 \mathrm{MPa}$,

$f_{s c d}=540 / 1.15=470 \mathrm{MPa}$.

According to Eq. (24), the design and characteristic factors for concrete cracking and creep effects are: $K_{c d}=K_{c k}=0.25 /(1+1.7 \times 38.88 / 65.88)=0.125$.

Thus, the design and characteristic values of the effective flexural stiffness of columns by Eq. (25) are defined as:

$$
(E I)_{e d}=(E I)_{e k}=0.125 \times 2.824 \times 10^{4} \times 3.33 \times 10^{-4}+
$$

$2 \times 10^{5} \times 1.3 \times 10^{-5}=3.774 \mathrm{MNm}^{2}$. loads are:

Therefore, the design and characteristic buckling

$$
N_{B d}=N_{B k}=\pi^{2} \times 3.774 / 3.0^{2}=4.139 \mathrm{MN} .
$$

According to Eqs (21) and (20), the design and characteristic values of first- and second-order eccentricities of compressive forces $N_{E d}^{E N}, N_{E d}^{A S C E}$ and $N_{E k}$ are:

$$
\begin{aligned}
& e_{o d}^{E K}=65.88 / 944.7=0.0697 \mathrm{~m}, \\
& e_{d}^{E N}=0.0697\left(\frac{1}{1-0.9447 / 4.139}\right)=0.0903 \mathrm{~m}, \\
& e_{o d}^{A S C E}=62.31 / 852.4=0.0731 \mathrm{~m},
\end{aligned}
$$

$$
\begin{aligned}
& e_{d}^{A S C E}=0.0731\left(\frac{1}{1-0.852 / 4.139}\right)=0.09205 \mathrm{~m}, \\
& e_{o k}=48.55 / 705=0.069 \mathrm{~m}, \\
& e_{k}=0.069\left(\frac{1}{1-0.705 / 4.139}\right)=0.0903 \mathrm{~m} .
\end{aligned}
$$

Therefore, the design and characteristic response factors by Eqs (13) and (14) are written as:

$$
\begin{aligned}
& k_{c d}^{E N}=1-0.3 \frac{0.0903 / 0.12}{1+10 \times 0.0417}=0.841, \\
& k_{s d}^{E N}=1-0.34 \times 0.0903 / 0.12=0.744, \\
& k_{c k}=1-0.3 \frac{0.0832 / 0.12}{1+10 \times 0.0417}=0.853, \\
& k_{s k}=1-0.34 \times 0.0832 / 0.12=0.764 .
\end{aligned}
$$

According to EN 1990 [18] directions, the design values of resisting compressive force by Eq. (28) and bending moment by Eq. (29) of the column are:

$N_{R d}^{E N}=(0.841 \times 0.0434 \times 23.7+0.744 \times 0.00181 \times 600) \times$

$0.12 /(0.0903+0.12)=0.954 \mathrm{MN}>N_{E d}^{E N}=0.945 \mathrm{MN}$,

$M_{R d}^{E N}=1.2 \times 0.12(0.00181 \times 390+0.945) \times$

$\left[1-\frac{0.00181 \times 390+0.945}{0.0434 \times 23.7+0.00181(390+470)}\right]=$

$0.0859 \mathrm{MNm} \approx N_{E d}^{E N} e_{d}=0.945 \times 0.0903=0.0853 \mathrm{MNm}$.

According to ASCE/SEI 7-05 (2006) recommendations, the design values of resisting compressive force by Eq. (35) and bending moment by Eq. (36) of the column are: 


$$
\begin{aligned}
& N_{R d}^{A S C E}=0.65(0.85 \times 0.0434 \times 36.48+0.764 \times 0.00181 \times \\
& 690) \times 0.12 /(0.0832+0.12)=0.882 \mathrm{MN}> \\
& N_{E d}^{A S C E}=0.852 \mathrm{MN}, \\
& M_{R d}^{A S C E}=0.65 \times 1.2 \times 0.12(0.00181 \times 450+0.705) \times \\
& {\left[1-\frac{0.00181 \times 450+0.705}{0.0434 \times 35.48+0.00181(450+540)}\right]=} \\
& 0.0782 \mathrm{MNm} \approx N_{E d}^{A S C E} e_{d}^{A S C E}=0.852 \times 0.09205= \\
& 0.0785 \mathrm{MNm} .
\end{aligned}
$$

According to both limit state design methods, the analysed columns are suitable in service. Their analysis results slightly depended on the methodological concepts of PSFD and LRFD approaches, presented in EN 1990 (2002) and ASCE/SEI 7-05 (2006), respectively.

\section{Conclusion}

The concepts of the compression with a bending moment and the bending with a concentrical force may be successfully used in the structural analysis of eccentrically loaded fairly complicated spun concrete columns reinforced by high-strength steel bars uniformly distributed throughout their annular cross-sections. The positive mechanical features of high-strength reinforcing steel bars may be successfully used in the design practice of any in-situ or precast reinforced concrete columns and other compression members.

When the eccentricity ratio $e / r_{s} \leq 1$, it is expedient to treat these columns as structural members exposed to compression with a bending moment. In this case, the bearing capacity of columns as their resisting compressive force may be calculated by Eq. (15). The fitness of this equation is corroborated by abundant experimental data.

The design values of resisting compressive forces and bending moments of columns may be calculated by unsophisticated Eqs (28), (29) and (35), (36) recommended in this paper and adapted, respectively, to the current methods of partial safety factors design (PSFD) in Europe and load and resistance factors design (LRFD) in the USA. Regardless of their features, both design methods lead to the close analysis results of eccentrically loaded columns.

\section{References}

ACI 318-05. 2005. Building code requirements for structural concrete. American Concrete Institute, Farmington Hills, Mich.

ASCE/SEI 7-05. 2006. Minimum design loads for buildings and other structures, ASCE.

Dilger, W. H.; Rao, S. V. K. M. 1997. High performance concrete mixtures for spun cast concrete poles, PCI Journal 42(4): 82-89.

Diniz, S. M. C. 2002. Long-term reliability of eccentricallyloaded HSC columns, in 6th International Symposium on Utilization of High Strength/high Performance Concrete, Leipzig, Germany, 1601-1615.
Diniz, S. M. C. 2005. Effect of concrete age specification on the reliability of HSC columns, ICOSSAR, G. Augusti, G. J. Schuëller, M. Ciampoli (Eds.), Millpress, Rotterdam: $565-572$.

Ellingwood, B. R. 1981. Wind and snow load statistics for probabilistic design, J. Struct Div, ASCE 107(7): 1345-49.

EN 1990. Eurocode - Basis of structural design. Brussels, CEN; 2002.

EN 1992-1, Eurocode 2: Design of concrete structures - Part 1: General rules and rules for buildings, Brussels; 2004.

Hussaini, A. Al.; Regan, P. E.; Xue, K.; Ramdane, E. 1993. The behaviour of HSC columns under axial load, in HighStrength Concrete, Proceeding 1, June Lilehammer, Norway, 83-89.

JCSS. 2000 Probabilistic model code: Part 1-Basis of design, 12 th draft.

Kaufmann, J. P.; Hesselbarth, Moser K.; Terrasi, G. P. 2005. Application of fiber reinforced high performance composites in spun-cast elements, Materials and Structures 38: $549-555$.

Kudzys, A.; Kliukas, R. 2008 a. Precast spun concrete piers in road bridges and footbridges, The Baltic Journal of Road and Bridge Engineering 3(4): 187-197. doi:10.3846/1822-427X.2008.3.187-197

Kudzys, A. and Kliukas, R. 2008 b. The resistance of compressed spun concrete members reinforced by high-strength steel bars, Materials and Structures 41: 419-430. doi:10.1617/s11527-007-9255-8

Kudzys, A.; Kliukas, R.; Kudzys, A. 2007. On design features of propped and unpropped hyperstatic structures, Journal of Civil Engineering and Management 13(2): 131-141.

Kudzys, A.; Kliukas, R.; Vadlūga, R. 1993. Utilization of highstrength spun concrete and reinforcing steel in compressive structures, in High-Strength Concrete, Proceedings, Vol. 1, Norway, 259-268.

Kuranovas, A.; Kvedaras, A. K. 2007. Behaviour of hollow concrete-filled steel tubular composite elements, Journal of Civil Engineering and Management 13(2): 131-141.

MacGregor, J. G. 1988. Reinforced Concrete, Mechanics and Design. Practice-Hall International Inc.

Mosley, B.; Bungey, J.; Hulse, R. 2007. Reinforced Concrete Design (sixth edition).

Oliphant, W. J.; Wong, C. J. 2002. Spun concrete poles for electrical transmission structure applications-continuing to push the envelop of the technology, in Electrical Transmission in a New Age, Proceeding, dan E. Jackman (Ed.), ASCE/SEI, 241-248.

Quast, U. 2002. Columns and masts of prestressed spun concrete, in 6th International Symposium on Utilization of High Strength/High Performance Concrete, Leipzig, Germany, 519-526.

Soundararajan, A.; Shanmugasundaram, K. 2008. Flexural behaviour of concrete-filled steel hollow sections beams, Journal of Civil Engineering and Management 14(2): 107-114.

Szerszen, M. M.; Szwed, A.; Nowak, A. S. 2005. Reliability analysis for eccentrically loaded columns, ACI Structural Journal 102(5): 676-88.

Szerszen, M. M.; Nowak, A. S.; Swed, A. 2005. Reliability based sensitivity analysis of RC columns resistance, in ICOSSAR, G. Augusti, G. J. Schuëller, M. Ciampoli (Eds.). Millpress, Rotterdam, 2225-2230.

Walochnik, W. 1995. Fertigteilstuetzen aus Schleuderbeton, Die Bautechnik, Ausgabe A 72(8): 541-545 (in German). 
Вадлуга, Р. 1979. О практическом расчете по прочности бетонов и железобетонных элементов кольцевого сечения [Vadluga, R. Practical method of strength analysis of concrete and reinforced concrete ring cross-section], Железобетонные конструкции [Concrete Structures] 9: $49-58$.

Вадлуга, Р. 1985. Оценка прочности железобетонных элементов кольцевого сечения [Vadluga, R. The evaluation of strength of reinforced concrete members of ring cross- section], Железобетонные конструкиии [Concrete Structures] 14: 94-102.

Вадлуга, Р.; Клюкас, Р.; Гаралявичюс, Р. 1996. Оценка прочности и деформативности центрифугированного бетона [Vadluga, R. Kliukas, R.; Garalevičius, R. Strength and deformability estimation of centrifuged concrete], Statyba [Journal of Civil Engineering and Management] 4(8): 73-83.

\section{CENTRIFUGUOTOJO BETONO KOLONU PROJEKTAVIMAS RIBINIU BŪVIU METODU NAUDOJANT EN 1990 IR ASCE/SEI 7-05 REKOMENDUOJAMUS APKROVU DERINIUS}

\section{A. Kudzys, R. Kliukas}

\section{S a n tra k a}

Aptariamas didžiastiprio plieno strypais armuotų žiedinio skerspjūvio centrifuguotojo betono kolonų naudotinumas. Pateiktos armuotojo ir nearmuotojo centrifuguotojo betono medžiagų savybès, efektyvumo veiksniai ir laikomieji gniuždymo įtempiai. Ekscentriškai gniuždomų žiedinio skerspjūvio elementų laikomajai galiai modeliuoti taikomos lenkiamojo gniuždymo ir gniuždomojo lenkimo sampratos. Analizuojamas centriškai ir ekscentriškai apkrautų elementų eksperimentinių ir modeliavimo duomenų sugretinimas, nagrinėjamas Europos, JAV ir kitų šalių projektavimo praktikoje itteisintų ir paplitusių dalinių veiksnių ir apkrovų bei atsparių veiksnių metodų taikymo tikslingumas, kurį rodo skaitmeninis pavyzdys.

Reikšminiai žodžiai: centrifuguotasis betonas, didžiastipris plienas, gniuždymo bandymas, ekscentrinis apkrovimas, ribinių būvių metodas.

Antanas KUDZYS. Dr Habil, Professor of the Institute of Architecture and Construction of Kaunas Universitty of Technology, Tunelio g. 60, LT-44405 Kaunas, Lithuania.

Dr Habil (building structures, 1967). Author of 6 books, 5 textbooks for students, 4 dictionaries and more than 300 articles. Research interest: bearing capacity, safety and durability of structural members and their systems.

Romualdas KLIUKAS. Doctor, Assoc Prof, Dept of Strength of Materials, Vilnius Gediminas Technical University, Sauletekio al. 11, LT-10223 Vilnius, Lithuania.

PhD (building structures, 1989). Researcher at the Dept of Reinforced Concrete Structures of Vilnius Institute of Civil Engineering. Research visit to Building Scientific-Technical Research Centre (France) 1990-91. Author of over 40 articles. Research interests: capacity, durability and renovation of reinforced vibrated and spun concrete structures. 